\title{
Synthesis, Characterization, and Photocatalytic Activity of N-Doped ZnO/ZnS Composites
}

\author{
Hongchao Ma, Xiaohong Cheng, Chun Ma, Xiaoli Dong, Xinxin Zhang, Mang Xue, \\ Xiufang Zhang, and Yinghuan Fu
}

School of Chemistry Engineering and Material, Dalian Polytechnic University, Dalian, Liaoning 116034, China

Correspondence should be addressed to Xiaoli Dong; dongxl@dlpu.edu.cn and Yinghuan Fu; fuyinghuan@sina.com

Received 19 November 2012; Accepted 31 December 2012

Academic Editor: Raghu N. Bhattacharya

Copyright (c) 2013 Hongchao Ma et al. This is an open access article distributed under the Creative Commons Attribution License, which permits unrestricted use, distribution, and reproduction in any medium, provided the original work is properly cited.

\begin{abstract}
The aim of the present study is to enhance photocatalytic performance of $\mathrm{ZnO}$ semiconductor by comodification with doping of nonmetal ions and coupling with another semiconductor. Therefore, we synthesized the $\mathrm{N}$-doped $\mathrm{ZnO} / \mathrm{ZnS}$ photocatalysts via a simple heat-treatment approach using L-cysteine as $\mathrm{N}$ and $\mathrm{S}$ source in this work. Anthraquinone dye (reactive brilliant blue KNR) is employed as the model contaminants to evaluate the photocatalytic activity of as-synthesized samples under sunlight illumination. The $\mathrm{N}$-doped $\mathrm{ZnO} / \mathrm{ZnS}$ synthesized by this method shows better photocatalytic activity as compared to that of pure $\mathrm{ZnO}$. The enhanced photocatalytic activity of the $\mathrm{N}$-doped $\mathrm{ZnO} / \mathrm{ZnS}$ composites may be related to the existence of $\mathrm{N}$ doping, $\mathrm{ZnS} / \mathrm{ZnO}$ heterostructure, and covered abundant carbon species on the photocatalyst surface, which causing high absorption efficiency of light, efficient separation of electron-hole pairs, and quick surface reaction in doped $\mathrm{ZnO}$.
\end{abstract}

\section{Introduction}

Semiconductor photocatalysis is an efficient approach for environmental decontamination by the chemical utilization of solar energy [1-4], which is capable of converting the toxic and nonbiodegradable organic compounds into carbon dioxide and inorganic constituents. Among the various semiconductors applied, $\mathrm{TiO}_{2}$ is the most frequently employed photocatalyst owing to its cheapness, nontoxicity, and structural stability [5-8]. Currently, researchers show that $\mathrm{ZnO}$ has better activity in photocatalytic degradation of some organic contaminants compared to that of $\mathrm{TiO}_{2}[9-$ 11]. However, $\mathrm{ZnO}$ semiconductor has a wide band gap of about $3.37 \mathrm{eV}$, which results in that it is effective only under irradiation of UV-light region and suffers from low efficiency under visible light illumination. Thus, only approximately $3 \%-5 \%$ UV light of the solar energy that reaches the earth can be utilized for photocatalytic reactions when $\mathrm{ZnO}$ is used as the catalyst. Furthermore, the fast recombination of photogenerated electron-hole pairs also needs to be solved for its application [12]. Therefore, improving photocatalytic performance of $\mathrm{ZnO}$ by modification to reduce the band gap to make absorption in the visible region possible (use sunlight more efficiently) and to inhibit recombination of photogenerated electron-hole pairs has become a hot topic among researchers in recent years $[13,14]$.

Numerous efforts have been developed to overcome the drawbacks, such as depositing metals on $\mathrm{ZnO}$ surface $[15,16]$, doping with metals $\left(\mathrm{Co}^{2+}, \mathrm{Mg}^{2+}\right)$ or nonmetal ions $(\mathrm{C}, \mathrm{S}, \mathrm{N})$ [14, 17-19], or combining $\mathrm{ZnO}$ with another semiconductor $[20,21]$. Recently, nonmetal ions doped $\mathrm{ZnO}$ photocatalysts have attracted much attention in the photo-catalytic processes owing to that it can improve photocatalytic activity by enhancing absorption of light and transport of photogenerated charge carriers $[19,22]$. However, to the best of our knowledge, previous researches mostly regarded onefold modification of $\mathrm{ZnO}$ with non metal ions such as $\mathrm{C}, \mathrm{N}, \mathrm{S}$ co-doped $\mathrm{ZnO}$ or $\mathrm{C}, \mathrm{N}$ codoped $\mathrm{ZnS}$ photocatalysts [14, 23]; few studies have been done on comodification with doping of nonmetal ions and coupling with another semiconductor to enhance photocatalytic performance of semiconductor. Therefore, in the present work, we synthesized the N-doped $\mathrm{ZnO} / \mathrm{ZnS}$ photocatalysts with visible-light response via a simple heat-treatment approach using L-cysteine as $\mathrm{N}$ and $\mathrm{S}$ source. Anthraquinone dye (reactive brilliant blue $\mathrm{KN}-\mathrm{R}$ ) 
is employed as the model contaminants to evaluate the photocatalytic activity of as-synthesized samples under sunlight illumination. The $\mathrm{N}$-doped $\mathrm{ZnO} / \mathrm{ZnS}$ synthesized by this method shows better photocatalytic activity as compared to that of pure $\mathrm{ZnO}$.

\section{Experimental Details}

2.1. Synthesis. $2.875 \mathrm{~g} \mathrm{ZnSO}_{4} \cdot 7 \mathrm{H}_{2} \mathrm{O}(0.01 \mathrm{~mol}), 0.8 \mathrm{~g} \mathrm{NaOH}$ $(0.02 \mathrm{~mol})$, and desired amount of L-cysteine (the molar ratio of $\mathrm{Zn}$ to L-cysteine is $10: 1,5: 1,1: 1$, and $1: 5)$ were dissolved in $40 \mathrm{~mL}$ deionized water. After 10 min of stirring, the reaction mixture was evaporated on water bath at $90^{\circ} \mathrm{C}$ until dry mixture was obtained, followed by transferring into an annealing furnace and maintained at 300, 400, 500, and $600^{\circ} \mathrm{C}$ for $2 \mathrm{~h}$ in nitrogen atmosphere. After calcination, the powder was collected, washed with deionized water and anhydrous alcohol for three times, and dried at $80^{\circ} \mathrm{C}$ for $6 \mathrm{~h}$ to obtain $\mathrm{N}$-doped $\mathrm{ZnO} / \mathrm{ZnS}$ composites. For comparison, pure $\mathrm{ZnO}$ was prepared by the same process with synthesis of $\mathrm{N}, \mathrm{S}$ co-doped $\mathrm{ZnO}$ composite in absence of L-cysteine and calcined at $400^{\circ} \mathrm{C} 2 \mathrm{~h}$ in this process.

2.2. Characterizations. The products were characterized by X-ray powder diffraction on a Shimadzu XRD-6100 X-ray diffractometer with a graphite monochromatized CuKa radiation $(\lambda=1.5418 \AA)$. UV-visible diffuse reflectance spectra were recorded with a Varian Cary-100 spectrophotometer and barium sulfate was used as a standard. The surface structure of the as-prepared sample was determined by X-ray photoelectron spectroscopy (XPS) and was performed using VG EscaLab 250 SYSTEM (Thermo VG) with $\mathrm{Al} \mathrm{K} \alpha$ radiation $(1486.6 \mathrm{eV})$. The Cls photoelectron peak (binding energy at $284.6 \mathrm{eV}$ ) was used as energy reference. The PL spectra of $\mathrm{ZnO}$ microcrystal photocatalyst were measured by using a fluorescence spectrophotometer (PE-LS55, USA) equipped with a Xenon lamp at an excitation wavelength of $325 \mathrm{~nm}$.

2.3. Photocatalytic Activity Test. The photocatalytic activities of the samples were evaluated by the degradation of anthraquinone dye (reactive brilliant blue $\mathrm{KN}-\mathrm{R}$ ) in an aqueous solution. $200 \mathrm{~mL}$ anthraquinone dye aqueous solution with concentration of $20 \mathrm{mg} / \mathrm{L}$ was mixed with $20 \mathrm{mg} / \mathrm{L}$ catalysts, which was exposed to illumination of $500 \mathrm{~W}$ Xe lamp (as simulated sunlight source) with a maximum emission at about $470 \mathrm{~nm}$. Before turning on the lamp, the suspension containing reactive brilliant blue $\mathrm{KN}-\mathrm{R}$ and photocatalyst were magnetically stirred in a dark condition for $60 \mathrm{~min}$ till an adsorption-desorption equilibrium was established. Samples were then taken out regularly from the reactor and centrifuged immediately for separation of any suspended solid. The absorbance $A$ of transparent solution was measured by a $721 \mathrm{~B}$ spectrophotometer and the $A$ value was used to estimate the photocatalytic degradation rate $D$ of reactive brilliant blue K-NR according to the following equation:

$$
D=\frac{\left(A_{0}-A_{t}\right)}{A_{0}} \times 100 \%,
$$

where $A_{0}$ is the initial absorbance of reactive brilliant blue K$\mathrm{NR}, t$ is the reaction time, and $A_{t}$ is the absorbance at time $t$.

\section{Results and Discussion}

Figure 1(a) shows the XRD patterns of the $\mathrm{N}$-doped $\mathrm{ZnO} / \mathrm{ZnS}$ samples calcined at various temperatures. The main diffraction peaks can be indexed for hexagonal wurtzite $\mathrm{ZnO}$ (JCPDS card no. 36-1451) and sphalerite cubic ZnS phase (JCPDS card no. 5-0566) in XRD pattern of powders obtained by calcination at $300-500^{\circ} \mathrm{C}$. When the calcination temperature of as-synthesized sample reached $600^{\circ} \mathrm{C}$, the characteristic peaks of wurtzite $\mathrm{ZnS}$ phase is found, while all the characteristic peaks of sphalerite cubic $\mathrm{ZnS}$ disappeared. The XRD pattern of as-synthesized samples with different $\mathrm{Zn} / \mathrm{N}$ molar ratios is shown in Figure 1(b). It can be seen from Figure 1(b) that intensity of diffraction peaks corresponding to $\mathrm{ZnO}$ increases with increasing of $\mathrm{Zn} / \mathrm{N}$ atomic ratio, while intensity of diffraction peaks corresponding to $\mathrm{ZnS}$ decreases. The XRD patterns of the (100), (002), and (101) planes of the samples were shown in Figure 1(c). The peaks of these planes in $\mathrm{N}$-doped $\mathrm{ZnO} / \mathrm{ZnS}$ samples shift slightly to lower Bragg angle (by $0.07^{\circ}$ ) as compared to those of pure $\mathrm{ZnO}$. This shift suggests that the oxygen or $\mathrm{Zn}$ atoms in the lattice of doped $\mathrm{ZnO}$ samples may be substituted by other atoms. We consider that the position of diffraction peaks in doped samples shifts to lower Bragg angle, which may be contributed to the fact that atomic radius of $\mathrm{N}$ is greater than $\mathrm{O}$ and smaller than $\mathrm{Zn}$; it is suggested that $\mathrm{N}$ is substituted on $\mathrm{O}$ sites [24].

The optical properties of the as-synthesized samples were probed by UV-visible diffuse reflectance spectroscopy. Figure 2 shows the transformed UV-vis absorption spectra of the as-synthesized samples together with the band-gap values, evaluated by linear extrapolation (the intercept on the $x$-axis gives the value of the band gap). The spectrum of pure $\mathrm{ZnO}$ is also included for comparison. From Figure 2, it is clear that $\mathrm{N}$-doped $\mathrm{ZnO} / \mathrm{ZnS}$ samples show obvious red shift as compared to those of pure $\mathrm{ZnO}$. It is found that the band-gap of $\mathrm{N}$-doped $\mathrm{ZnO} / \mathrm{ZnS}$ samples decreases with the increasing of the $\mathrm{Zn} / \mathrm{N}$ molar ratios. Oppositely, the change of band gap with heat treating is irregular, which suggests that the effect of heat treating on structure of photocatalysts may be more complex. Nevertheless, a minimum value of band gap $(2.98 \mathrm{eV})$ can be observed in $\mathrm{N}$-doped $\mathrm{ZnO} / \mathrm{ZnS}$ sample with $\mathrm{Zn} / \mathrm{N}=1$ prepared by calcination at $400^{\circ} \mathrm{C}$. The red shift of the band-gap absorption edge for $\mathrm{N}$-doped $\mathrm{ZnO} / \mathrm{ZnS}$ can be associated with the formed impurity states in the band gap by the partial substitution of $\mathrm{O}$ with other atoms in the crystal lattice of $\mathrm{ZnO}$ [22]. Thus, the $\mathrm{N}$-doped $\mathrm{ZnO} / \mathrm{ZnS}$ can be used as an efficient photocatalyst under sunlight irradiation.

The PL spectrum of the samples was measured by an excitation wavelength of $325 \mathrm{~nm}$ at room temperature and shown in Figure 3. The PL peak at about $390-400 \mathrm{~nm}$ was observed for doped $\mathrm{ZnO}$ and pure $\mathrm{ZnO}$. The PL peak can be contributed to the recombination of photo-generated electrons and holes [25, 26]. It can be seen that from Figure 3 the $\mathrm{N}$-doped $\mathrm{ZnO} / \mathrm{ZnS}$ composites showed lower intensity of PL peak located at $390-400 \mathrm{~nm}$ than that of pure $\mathrm{ZnO}$, especially the composite with $1: 1$ of $\mathrm{Zn} / \mathrm{N}$ atomic ratio showed lowest PL intensity. The PL spectra indicate that the effect of doped impurities on the recombination of photogenerated charges depended on the content of impurities. 


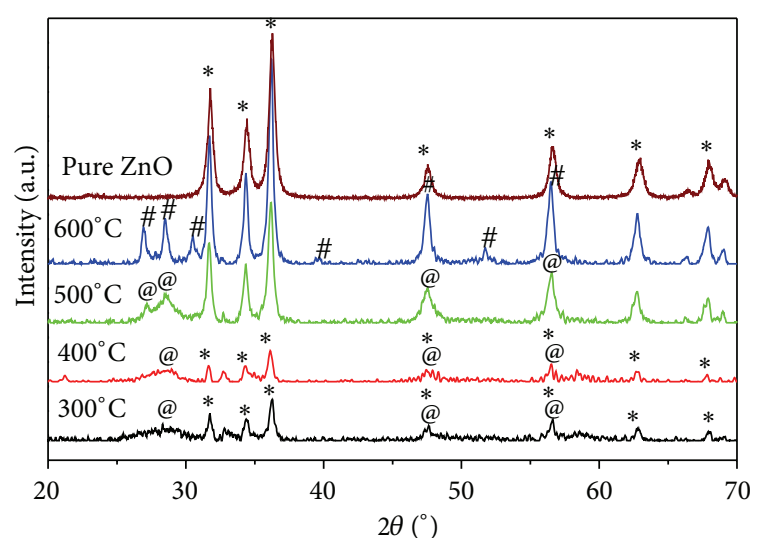

\# ZnS (JCPDS card no. 36-1450)

@ ZnS (JCPDS card no. 5-0566)

* ZnO (JCPDS card no. 36-1451)

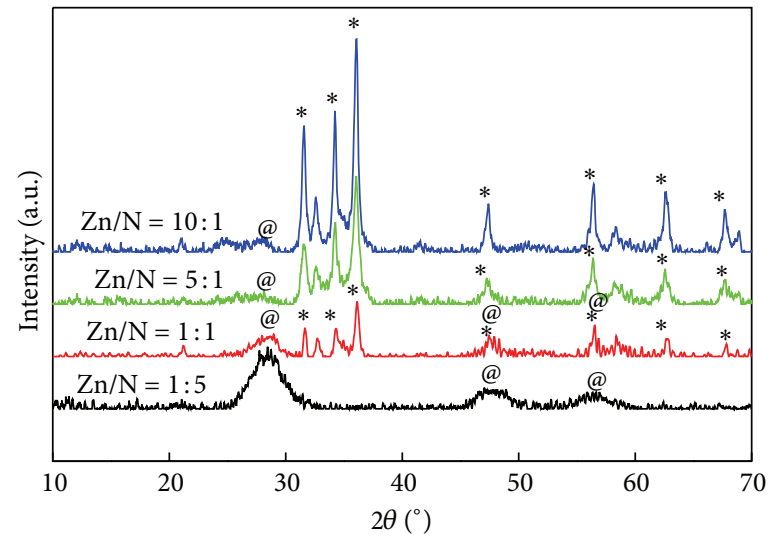

@ ZnS (JCPDS card no. 5-0566)

* ZnO (JCPDS card no. 36-1451)

(a)

(b)

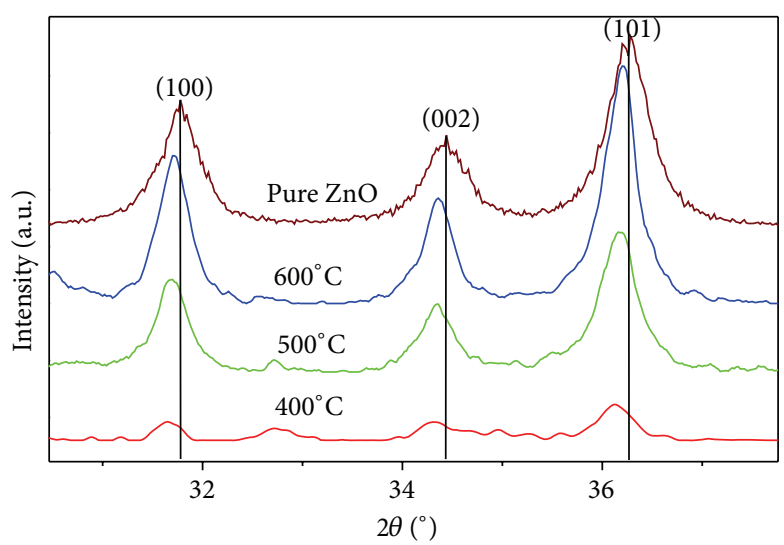

* ZnO (JCPDS card no. 36-1451)

(c)

FIGURE 1: XRD patterns of as-synthesized samples: (a) samples with $\mathrm{Zn} / \mathrm{N}=1: 1$ molar ratios calcined at different temperatures, (b) samples with different $\mathrm{Zn} / \mathrm{N}$ molar ratios calcined at $400^{\circ} \mathrm{C}$, and (c) comparison for peaks position between $\mathrm{N}$-doped $\mathrm{ZnO} / \mathrm{ZnS}$ composites and pure $\mathrm{ZnO}$.

The excessive impurities would form recombination center of photo-generated charges, which improved their recombination. The PL results demonstrated that impurity doping can inhibit the recombination between photogenerated holes and electrons, which is beneficial for the photocatalytic reaction.

The surface composition and chemical state of assyn-thesized samples were determined by XPS analysis. Figure 4(a) shows the whole scanning spectrum of assynthesized samples. The stronger signals of S2p, C1s and a weak signal corresponding to N1s were observed in doped $\mathrm{ZnO}$ sample as compared to those of pure $\mathrm{ZnO}$, which indicates $\mathrm{S}, \mathrm{N}$, and $\mathrm{C}$ elements exist in doped $\mathrm{ZnO}$ sample. The C1s XPS spectrum of doped $\mathrm{ZnO}$ was fitted to three peaks at 284.5, $286.5 \mathrm{eV}$, and $288.3 \mathrm{eV}$ (see Figure 4(b)). The peak with a binding energy of $284.5 \mathrm{eV}$ can be assigned to adventitious carbon adsorbed on the surface of the sample [27]. The other two peaks at 286.5 and $288.3 \mathrm{eV}$ can be assigned to the existence of $\mathrm{Zn}-\mathrm{O}-\mathrm{C}$ and $\mathrm{C}=\mathrm{O}$ of carbonate species, respectively $[28,29]$. The peak around $282 \mathrm{eV}$ resulting from carbon interacting with $\mathrm{Zn}$ through $\mathrm{Zn}-\mathrm{C}$ bond formation was not observed [30], which suggests that new chemical state of carbon species $(\mathrm{Zn}-\mathrm{C})$ is not formed during the doping process. Even so, the existence of abundant carbon species on the surface of composite still is beneficial for photocatalytic process because it can set in contact with external pollutant molecules.

Figure 4(c) shows the high resolution XPS spectra of N1s region for doped $\mathrm{ZnO}$ sample and its fitting curves. It can be 


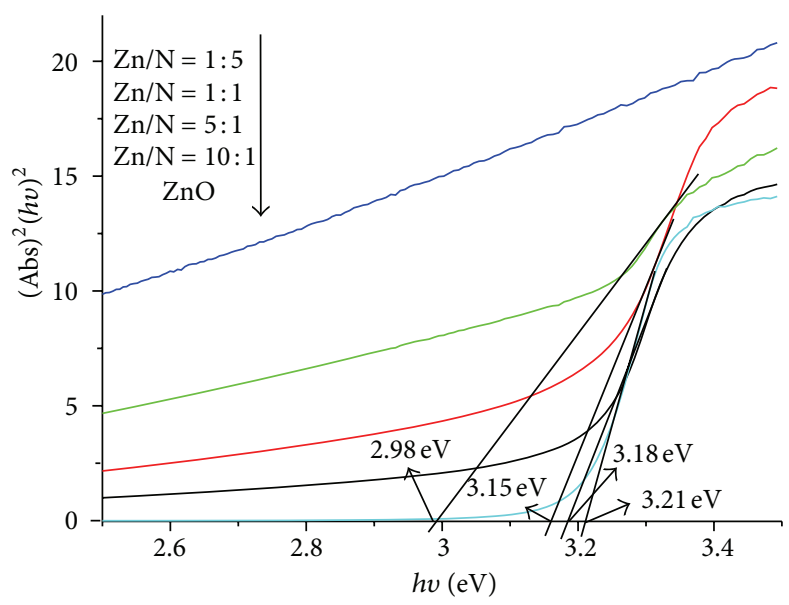

(a)

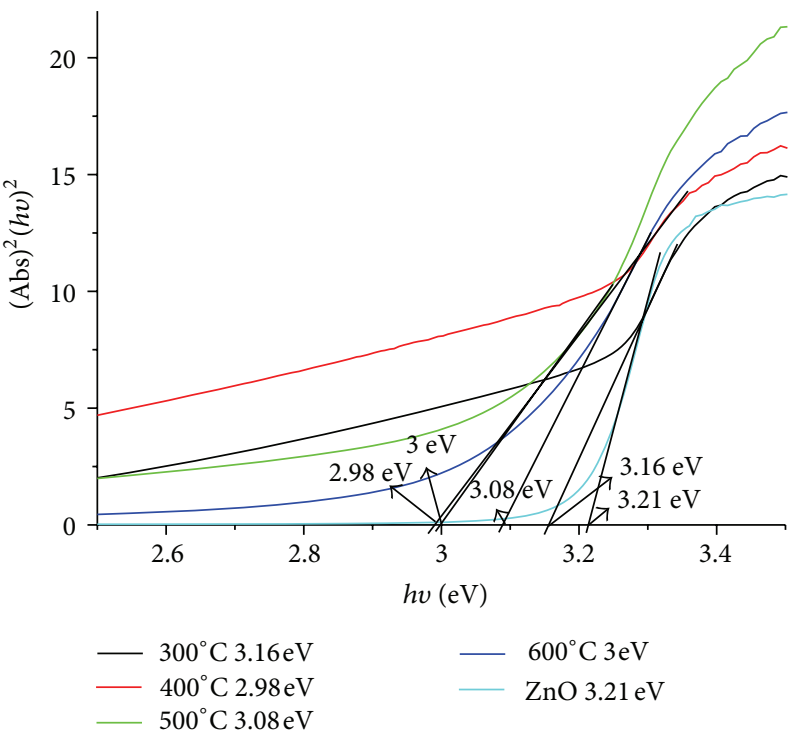

(b)

FIGURE 2: UV-vis absorption spectra in the band-gap region of samples: (a) samples with different $\mathrm{Zn} / \mathrm{N}$ molar ratios calcined at; $400^{\circ} \mathrm{C}$; (b) samples with $\mathrm{Zn} / \mathrm{N}=1: 1$ molar ratios calcined at different temperatures.

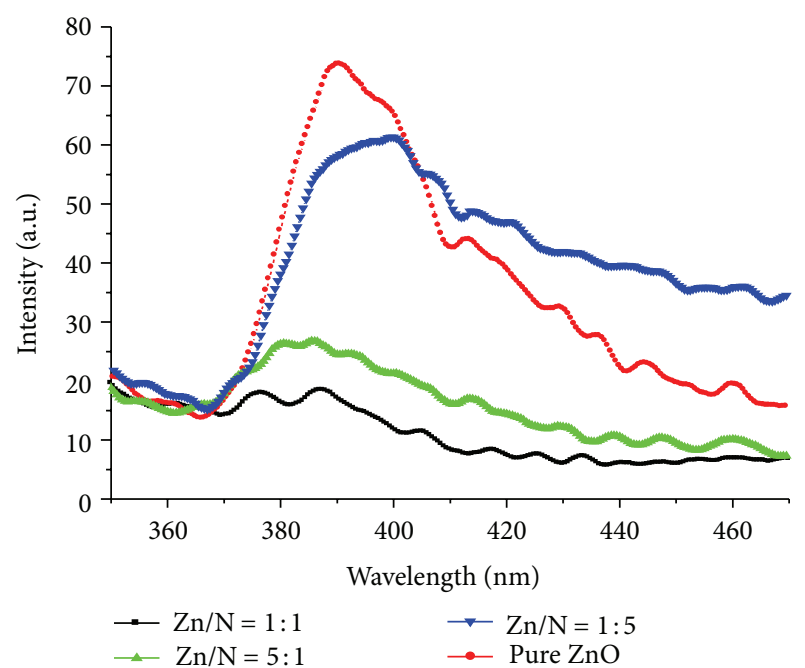

FIgURE 3: Photoluminescence spectra of samples with different $\mathrm{Zn} / \mathrm{N}$ molar ratios calcined at $400^{\circ} \mathrm{C}$.

seen that a peak centered at $398.8 \mathrm{eV}$ for the doped sample is obtained, which can be ascribed to the anionic $\mathrm{N}^{-}$in the form of $\mathrm{N}-\mathrm{Zn}$ bonds [31-34]. Thus the XPS data supports the incorporation of $\mathrm{N}$ into the $\mathrm{ZnO}$. The substitutional $\mathrm{N}$ may be related to the active sites for the photocatalysts [35]. The high resolution XPS spectrum of the S2p region of doped $\mathrm{ZnO}$ sample is shown in Figure 4(d). It can be seen that the peak of S2p contains two isolated bands centered at 169.2 and $161.8 \mathrm{eV}$, which can be attributed to the $\mathrm{S}^{4+} / \mathrm{S}^{6+}$ and $\mathrm{S}^{2-}$ according to the data reported in the literature [28, 36-39]. Thus, based on mentioned XRD, UV-vis, and XPS analysis it can be reasonable to deduce that the $\mathrm{N}$-doped $\mathrm{ZnO} / \mathrm{ZnS}$ composite was successfully synthesized by simple heat-treated process.

The high resolution XPS spectra of Ols band of assynthesized samples are shown in Figure 4(e). The O1s peak was fitted to two components centered at about 529.8$530.5 \mathrm{eV}$ and $531.5-532.0 \mathrm{eV}$, respectively. The low binding energy component at $529.8-530.5 \mathrm{eV}$ was attributed to $\mathrm{O}^{2-}$ ions of $\mathrm{ZnO}$ [40], while another at 531.5-532.0 eV usually corresponds to oxygen in adsorbed $\mathrm{O}_{2}$ or $\mathrm{OH}^{-}$groups on the $\mathrm{ZnO}$ surface [41-43]. In this study, it is considered that some $\mathrm{S}, \mathrm{C}$, and $\mathrm{N}$ atoms may bound to oxygen in the sample; the peak at $531.5-532.0 \mathrm{eV}$ may also be assigned to $\mathrm{O}$ bound to $\mathrm{S}, \mathrm{N}$, or $\mathrm{C}$ atom [14]. In addition, from the high resolution XPS spectra of $Z n 2 p_{3 / 2}$ (Figure $4(f)$ ), it can be seen that the $\mathrm{Zn} 2 \mathrm{p}_{3 / 2}$ peaks of pure $\mathrm{ZnO}$ and doped $\mathrm{ZnO}$ appears at 1020.8 and $1023.6 \mathrm{eV}$, respectively. It is clear that the binding energy of $\mathrm{Zn} 2 \mathrm{p}_{3 / 2}$ peak of doped $\mathrm{ZnO}$ is higher as compared to that of the pure $\mathrm{ZnO}$. The shift of $\mathrm{Zn} 2 \mathrm{p}_{3 / 2}$ peak for doped $\mathrm{ZnO}$ can be ascribed to the doping or incorporation of $\mathrm{N}$ ions into $\mathrm{ZnO}$ powders and the existence of $\mathrm{Zn}-\mathrm{S}$ bond structure $[44,45]$.

The photocatalytic evaluation of as-synthesized samples is carried out for degradation of reactive brilliant blue $\mathrm{KN}-\mathrm{R}$. The straight lines for all reactions were obtained when $\ln \left(C_{0} / C_{t}\right)$ was plotted against time (see Figure 5), which indicated that the photodegradation process corresponds well to pseudofirst-order kinetics. It can be seen that the $\mathrm{N}$-doped $\mathrm{ZnO} / \mathrm{ZnS}$ composites exhibited higher photodegradation rate than the pure $\mathrm{ZnO}$. The improvement of photocatalytic activity for $\mathrm{N}$-doped $\mathrm{ZnO} / \mathrm{ZnS}$ should be related to the nitrogen doping, $\mathrm{ZnS} / \mathrm{ZnO}$ hetero-structure, and covered carbon species on the photocatalyst surface, which causing high absorption efficiency of light, efficient separation of electron-hole pairs, and quick surface reaction 


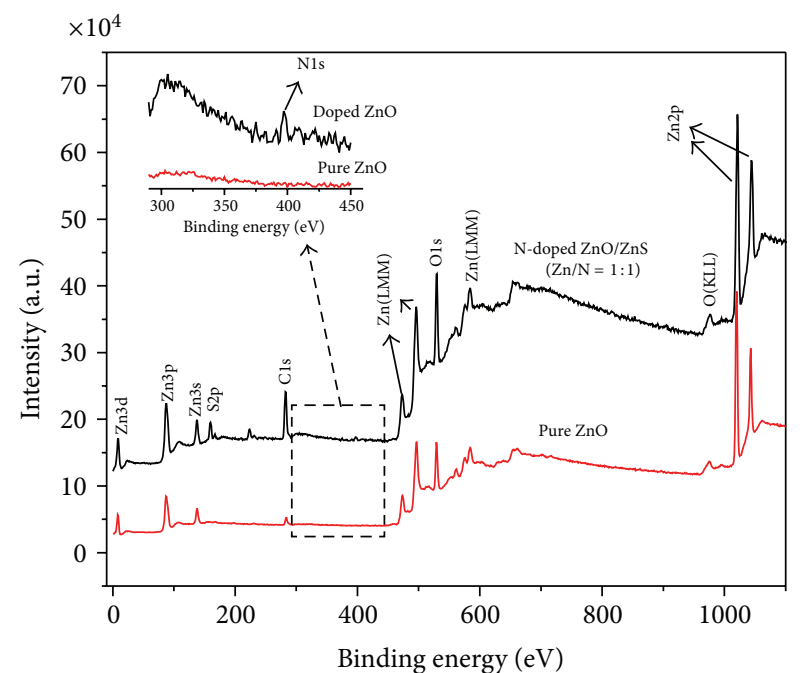

(a)

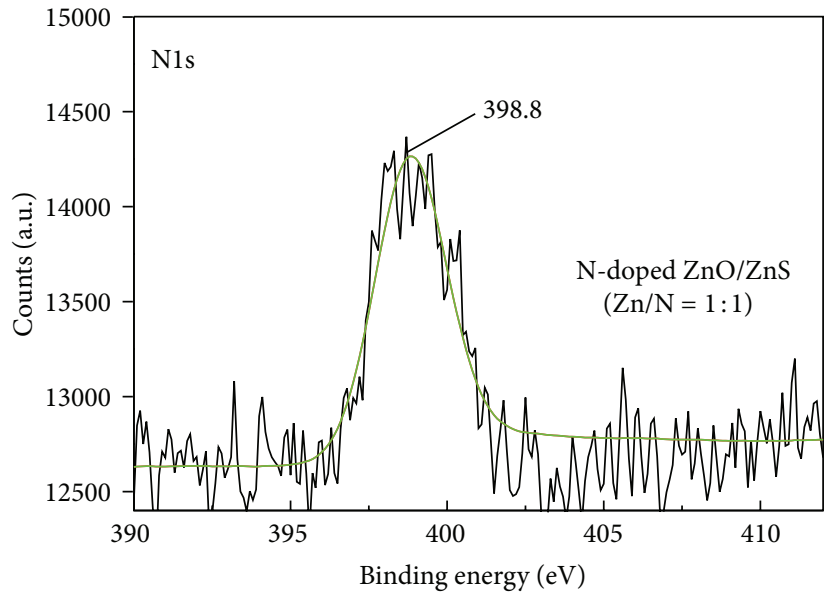

(c)

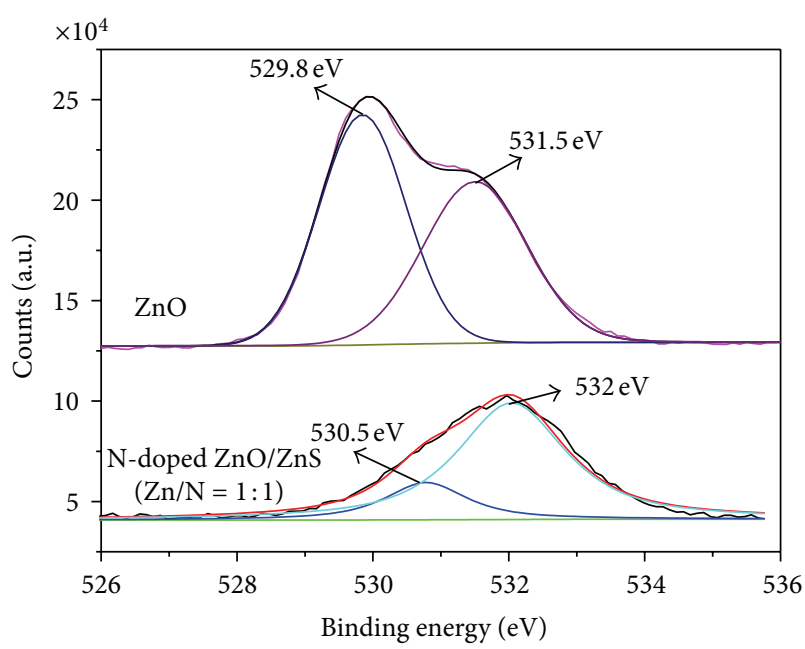

(e)

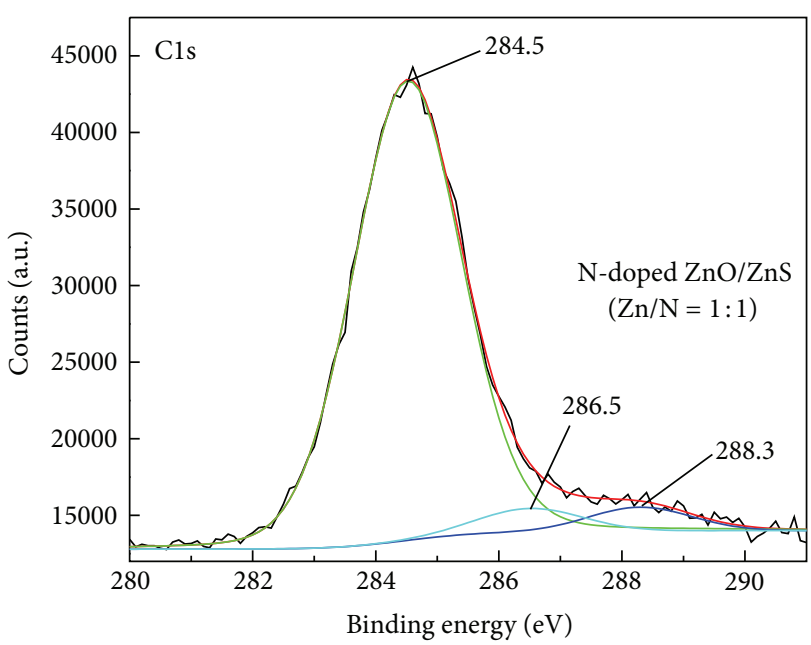

(b)

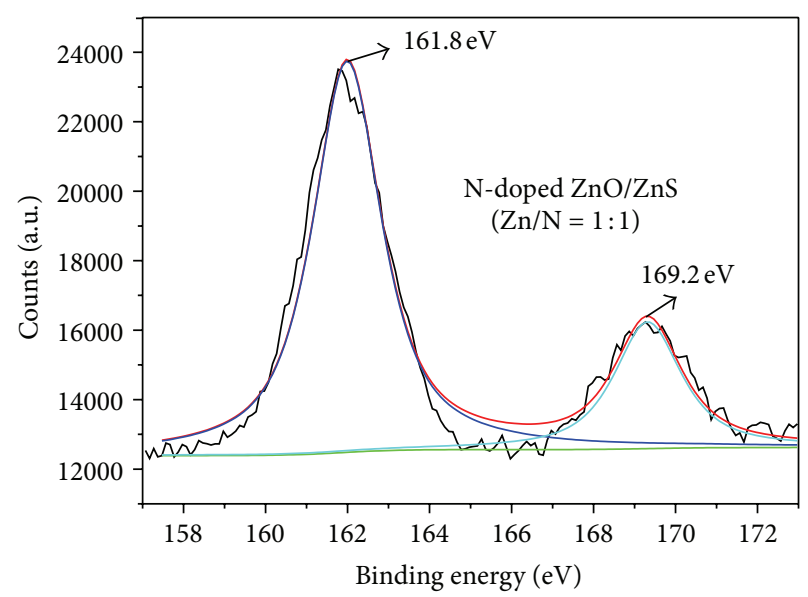

(d)

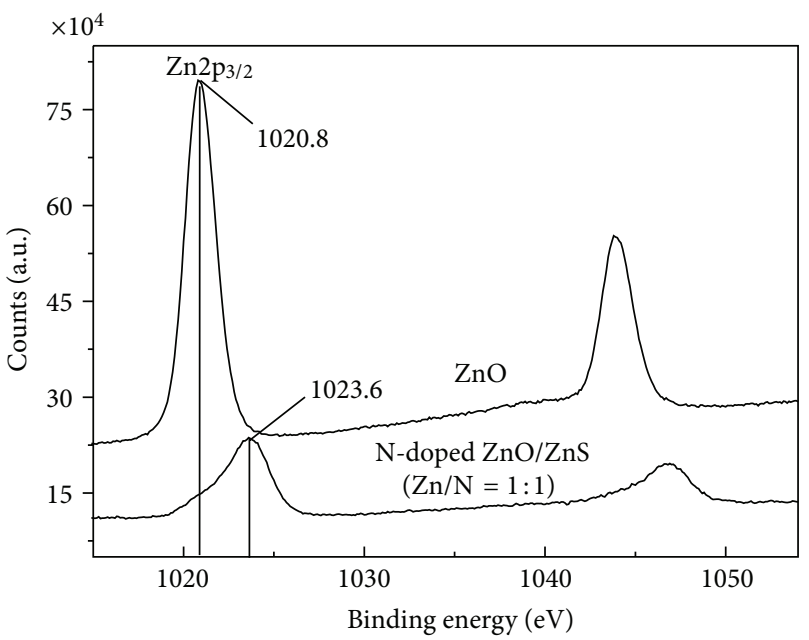

(f)

FiguRE 4: XPS spectra of samples: (a) XPS survey spectra, (b) C1s, (c) N1s, (d) S2p, (e) O1s, and (f) Zn2p state. 


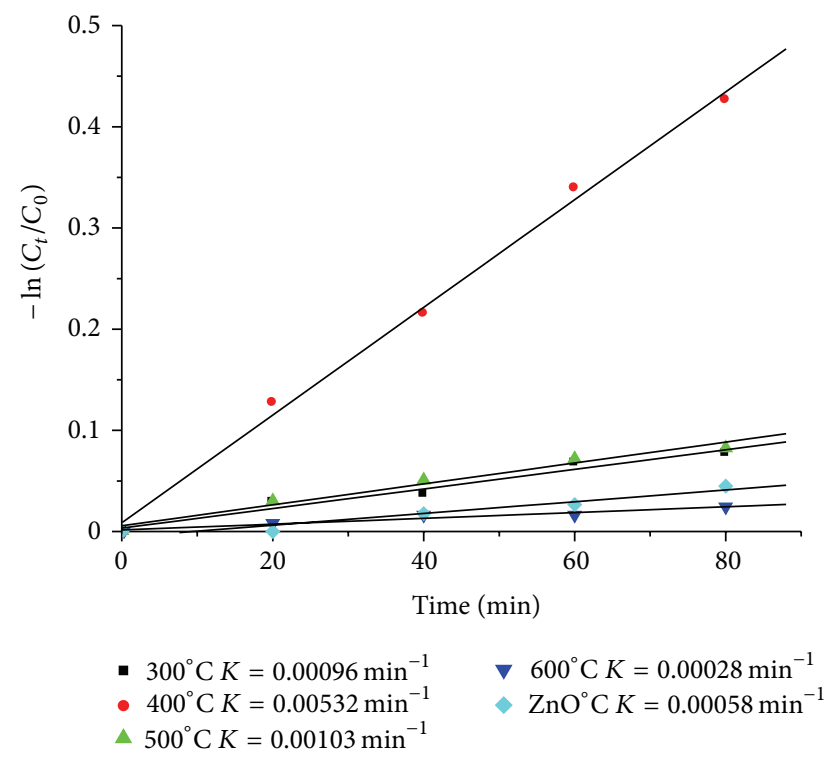

(a)

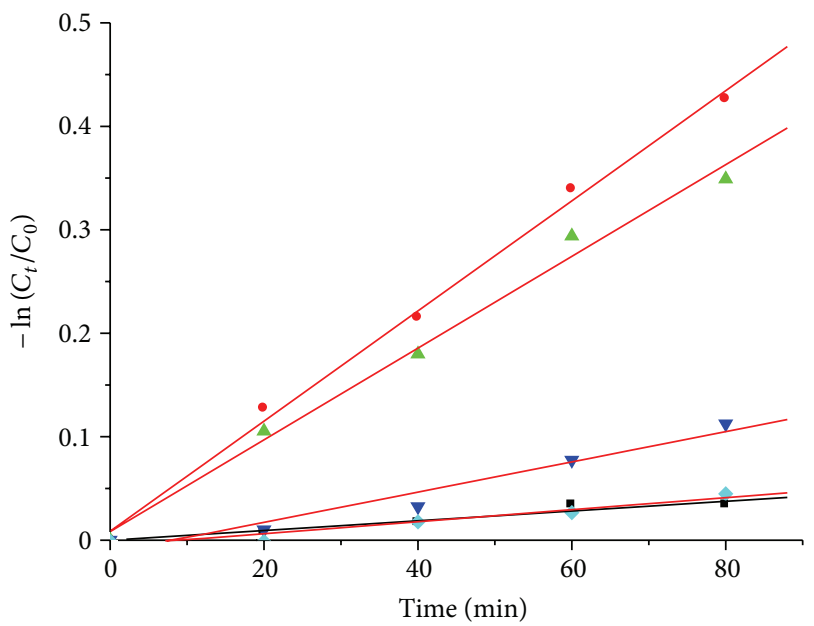

- $\mathrm{Zn} / \mathrm{N}=1: 5, K=0.00047 \mathrm{~min}^{-1}$

- $\mathrm{Zn} / \mathrm{N}=1: 1, K=0.0053 \mathrm{~min}^{-1}$

$\triangle \mathrm{Zn} / \mathrm{N}=5: 1, K=0.0044 \mathrm{~min}^{-1}$

$\nabla \mathrm{Zn} / \mathrm{N}=10: 1, K=0.00146 \mathrm{~min}^{-1}$

ZnO, $K=0.00058 \mathrm{~min}^{-1}$

(b)

Figure 5: Plots of degradation of KN-R over as-synthesized samples under visible light irradiation; (a) $\mathrm{N}$-doped $\mathrm{ZnO} / \mathrm{ZnS}$ photocatalysts with $\mathrm{Zn} / \mathrm{N}=1$ prepared at different temperatures for $2 \mathrm{~h}$. (b) $\mathrm{N}$ doped $\mathrm{ZnO} / \mathrm{ZnS}$ photocatalysts with various $\mathrm{Zn} / \mathrm{N}$ ratios prepared at $400^{\circ} \mathrm{C}$ for $2 \mathrm{~h}$.

in doped $\mathrm{ZnO}$. The $\mathrm{N}$-doped $\mathrm{ZnO} / \mathrm{ZnS}$ composite obtained under optimum conditions $(\mathrm{Zn} / \mathrm{N}=1: 1$ and heat treated at $400^{\circ} \mathrm{C}$ for $2 \mathrm{~h}$ ) has a highest degradation rate, and the apparent rate constant $k$ was $0.0053 \mathrm{~min}^{-1}$. The photodegradation rate of the $\mathrm{N}$-doped $\mathrm{ZnO} / \mathrm{ZnS}$ composite prepared at optimum conditions is about 9.1 times more than that of pure $\mathrm{ZnO}$ for reactive brilliant blue $\mathrm{KN}$ - $\mathrm{R}$ degradation under sunlight irradiation. It is well known that the stability of the $\mathrm{ZnO}$ is an important concern for the repeated use of the

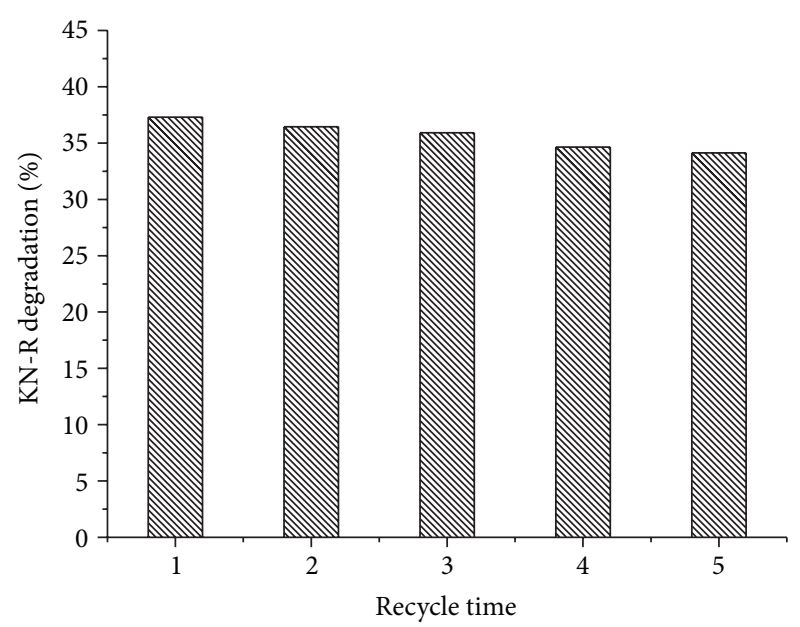

FIgure 6: The photocatalytic cycling tests of N-doped $\mathrm{ZnO} / \mathrm{ZnS}$ composite obtained under optimum conditions $(\mathrm{Zn} / \mathrm{N}=1: 1$ and heat treated at $400^{\circ} \mathrm{C}$ for $2 \mathrm{~h}$ ).

photocatalysts, so the photodegradative cycling experiments were carried out under sunlight irradiation, and each run lasted $120 \mathrm{~min}$ (see Figure 6). The results in Figure 6 show that the photocatalytic activity of $\mathrm{N}$-doped $\mathrm{ZnO} / \mathrm{ZnS}$ composite does not exhibit any great loss in activity even after five times, which implied that the stability of $\mathrm{N}$-doped $\mathrm{ZnO} / \mathrm{ZnS}$ composite is suitable for the photodegradation process of pollutants.

\section{Conclusions}

In this work, the $\mathrm{N}$-doped $\mathrm{ZnO} / \mathrm{ZnS}$ composites were synthesized by simple heat-treating method using L-cysteine as $\mathrm{N}$ and $\mathrm{S}$ source. The XRD, XPS, UV-vis DRS, and PL studies showed that the $\mathrm{N}$ is incorporated to $\mathrm{ZnO} / \mathrm{ZnS}$ composites, which shifted the band-gap absorption edge to visible light region and inhibited recombination of photogenerated electron-hole pairs. Hence, the as-synthesized N-doped $\mathrm{ZnO} / \mathrm{ZnS}$ composites show better photodegradation rate of reactive brilliant blue $\mathrm{KN}-\mathrm{R}$ as compared to that of pure $\mathrm{ZnO}$ under sunlight irradiation. The photo-degradation rate of $\mathrm{N}$-doped $\mathrm{ZnO} / \mathrm{ZnS}$ composite prepared under optimum conditions $\left(\mathrm{Zn}-\mathrm{N}=1: 1\right.$ and heat treated at $400^{\circ} \mathrm{C}$ for $\left.2 \mathrm{~h}\right)$ was found to be 9.1-times greater than that of pure $\mathrm{ZnO}$.

\section{Acknowledgments}

This work was supported by the National Natural Science Foundation of China (21243005), Science and Technology Foundation of Liaoning of China (201102111), Program for Key Science and Technology Platform in Universities of Liaoning Province, Program for Liaoning Excellent Talents in University (LGQ-2011-054, LR2011011), and Science \& Technology Public-Benefit Foundation of Liaoning of China ([2011]49). 


\section{References}

[1] N. Sobana and M. Swaminathan, "The effect of operational parameters on the photocatalytic degradation of acid red 18 by ZnO," Separation and Purification Technology, vol. 56, no. 1, pp. 101-107, 2007.

[2] M. Mrowetz and E. Selli, "Photocatalytic degradation of formic and benzoic acids and hydrogen peroxide evolution in $\mathrm{TiO}_{2}$ and $\mathrm{ZnO}$ water suspensions," Journal of Photochemistry and Photobiology A, vol. 180, no. 1-2, pp. 15-22, 2006.

[3] K. Chiang, T. M. Lim, L. Tsen, and C. C. Lee, "Photocatalytic degradation and mineralization of bisphenol $\mathrm{A}$ by $\mathrm{TiO}_{2}$ and platinized $\mathrm{TiO}_{2}$," Applied Catalysis A, vol. 261, no. 2, pp. 225237, 2004.

[4] H. Lachheb, E. Puzenat, A. Houas et al., "Photocatalytic degradation of various types of dyes (Alizarin S, Crocein Orange G, Methyl Red, Congo Red, Methylene Blue) in water by UVirradiated titania," Applied Catalysis B, vol. 39, no. 1, pp. 75-90, 2002.

[5] A. L. Linsebigler, G. Lu, and J. T. Yates, "Photocatalysis on $\mathrm{TiO}_{2}$ surfaces: principles, mechanisms, and selected results," Chemical Reviews, vol. 95, no. 3, pp. 735-758, 1995.

[6] A. Fujishima, T. N. Rao, and D. A. Tryk, "Titanium dioxide photocatalysis," Journal of Photochemistry and Photobiology C, vol. 1, no. 1, pp. 1-21, 2000.

[7] S. Klosek and D. Raftery, "Visible light driven V-doped $\mathrm{TiO}_{2}$ photocatalyst and its photooxidation of ethanol," Journal of Physical Chemistry B, vol. 105, no. 14, pp. 2815-2819, 2002.

[8] C. Kormann, D. W. Bahnemann, and M. R. Hoffmann, "Environmental photochemistry: is iron oxide (hematite) an active photocatalyst? A comparative study: $\alpha-\mathrm{Fe}_{2} \mathrm{O}_{3}, \mathrm{ZnO}, \mathrm{TiO}_{2}$," Journal of Photochemistry and Photobiology A, vol. 48, no. 1, pp. 161$169,1989$.

[9] F. Peng, H. Wang, H. Yu, and S. Chen, "Preparation of aluminum foil-supported nano-sized $\mathrm{ZnO}$ thin films and its photocatalytic degradation to phenol under visible light irradiation," Materials Research Bulletin, vol. 41, no. 11, pp. 2123-2129, 2006.

[10] D. Li and H. Haneda, "Morphologies of zinc oxide particles and their effects on photocatalysis," Chemosphere, vol. 51, no. 2, pp. 129-137, 2003.

[11] C. Hariharan, "Photocatalytic degradation of organic contaminants in water by $\mathrm{ZnO}$ nanoparticles," Applied Catalysis A, vol. 304, pp. 55-61, 2006.

[12] M. Romero, J. Blanco, B. Sánchez et al., "Solar photocatalytic degradation of water and air pollutants: challenges and perspectives," Solar Energy, vol. 66, no. 2, pp. 169-182, 1999.

[13] Y. Zheng, L. Zheng, Y. Zhan, X. Lin, Q. Zheng, and K. Wei, "Ag/ $\mathrm{ZnO}$ heterostructure nanocrystals: synthesis, characterization, and photocatalysis," Inorganic Chemistry, vol. 46, no. 17, pp. 6980-6986, 2007.

[14] L.-C. Chen, Y.-J. Tu, Y.-S. Wang, R.-S. Kan, and C.-M. Huang, "Characterization and photoreactivity of N-, S-, and C-doped $\mathrm{ZnO}$ under UV and visible light illumination," Journal of Photochemistry and Photobiology A, vol. 199, no. 2-3, pp. 170-178, 2008.

[15] J. Liqiang, W. Baiqi, X. Baifu et al., "Investigations on the surface modification of $\mathrm{ZnO}$ nanoparticle photocatalyst by depositing Pd," Journal of Solid State Chemistry, vol. 177, no. 11, pp. 42214227, 2004.
[16] W. Lu, S. Gao, and J. Wang, "One-pot synthesis of Ag/ZnO selfassembled 3D hollow microspheres with enhanced photocatalytic performance," Journal of Physical Chemistry C, vol. 112, no. 43, pp. 16792-16800, 2008.

[17] X. Qiu, G. Li, X. Sun, L. Li, and X. Fu, "Doping effects of $\mathrm{Co}^{2+}$ ions on $\mathrm{ZnO}$ nanorods and their photocatalytic properties," Nanotechnology, vol. 19, no. 21, Article ID 215703, 8 pages, 2008.

[18] X. Qiu, L. Li, J. Zheng, J. Liu, X. Sun, and G. Li, "Origin of the enhanced photocatalytic activities of semiconductors: a case study of $\mathrm{ZnO}$ doped with $\mathrm{Mg}^{2+}$," Journal of Physical Chemistry C, vol. 112, no. 32, pp. 12242-12248, 2008.

[19] J. Lu, Q. Zhang, J. Wang, F. Saito, and M. Uchida, "Synthesis of $\mathrm{N}$-Doped $\mathrm{ZnO}$ by grinding and subsequent heating $\mathrm{ZnO}$-urea mixture," Powder Technology, vol. 162, no. 1, pp. 33-37, 2006.

[20] M. L. Zhang, T. C. An, X. H. Hu, C. Wang, G. Y. Sheng, and J. M. $\mathrm{Fu}$, "Preparation and photocatalytic properties of a nanometer $\mathrm{ZnO}-\mathrm{SnO}_{2}$ coupled Oxide," Applied Catalysis A, vol. 260, no. 2, pp. 215-222, 2004.

[21] R. S. Mane, W. J. Lee, H. M. Pathan, and S. H. Han, "Nanocrystalline $\mathrm{TiO}_{2} / \mathrm{ZnO}$ thin films: fabrication and application to dyesensitized solar cells," Journal of Physical Chemistry B, vol. 109, no. 51, pp. 24254-24259, 2005.

[22] D. Li and H. Haneda, "Synthesis of nitrogen-containing $\mathrm{ZnO}$ powders by spray pyrolysis and their visible-light photocatalysis in gas-phase acetaldehyde decomposition," Journal of Photochemistry and Photobiology A, vol. 155, no. 1-3, pp. 171-178, 2003.

[23] M. Muruganandham and Y. Kusumoto, "Synthesis of N, C codoped hierarchical porous microsphere $\mathrm{ZnS}$ as a visible lightresponsive photocatalyst," Journal of Physical Chemistry C, vol. 113, no. 36, pp. 16144-16150, 2009.

[24] S. S. Shinde, C. H. Bhosale, and K. Y. Rajpure, "Photocatalytic degradation of toluene using sprayed $\mathrm{N}$-doped $\mathrm{ZnO}$ thin films in aqueous suspension," Journal of Photochemistry and Photobiology B, vol. 113, pp. 70-77, 2012.

[25] C. Chandrinou, N. Boukos, C. Stogios, and A. Travlos, "PL study of oxygen defect formation in $\mathrm{ZnO}$ nanorods," Microelectronics Journal, vol. 40, no. 2, pp. 296-298, 2009.

[26] G. R. Li, C. R. Dawa, Q. Bu et al., "Electrochemical self-assembly of $\mathrm{ZnO}$ nanoporous structures," Journal of Physical Chemistry C, vol. 111, no. 5, pp. 1919-1923, 2007.

[27] C. S. Gopinath, S. G. Hegde, A. V. Ramaswamy, and S. Mahapatra, "Photoemission studies of polymorphic $\mathrm{CaCO}_{3}$ materials," Materials Research Bulletin, vol. 37, no. 7, pp. 1323-1332, 2002.

[28] H. Q. Sun, Y. Bai, Y. P. Cheng, W. Q. Jin, and N. P. Xu, "Preparation and characterization of visible-light-driven carbon-sulfurcodoped $\mathrm{TiO}_{2}$ photocatalysts," Industrial \& Engineering Chemistry Research, vol. 45, no. 14, pp. 4971-4976, 2006.

[29] E. Papirer, R. Lacroix, J. B. Donnet, G. Nansé, and P. Fioux, "XPS study of the halogenation of carbon black-part 2. Chlorination," Carbon, vol. 33, no. 1, pp. 63-72, 1995.

[30] S. Cho, J. W. Jang, J. S. Lee, and K. H. Lee, "Carbon-doped ZnO nanostructures synthesized using vitamin $\mathrm{C}$ for visible light photocatalysis," CrystEngComm, vol. 12, no. 11, pp. 3929-3935, 2010.

[31] J. G. Ma, Y. C. Liu, R. Mu et al., "Method of control of nitrogen content in $\mathrm{ZnO}$ films: structural and photoluminescence properties," Journal of Vacuum Science \& Technology B, vol. 22, no. 1, pp. 94-98, 2004.

[32] X. Wang, J. C. Yu, Y. Chen, L. Wu, and X. Fu, " $\mathrm{ZrO}_{2}$-modified mesoporous nanocrystalline $\mathrm{TiO}_{2-\mathrm{x}} \mathrm{N}_{\mathrm{x}}$ as efficient visible light photocatalysts," Environmental Science and Technology, vol. 40, no. 7, pp. 2369-2374, 2006. 
[33] Y. F. Mei, R. K. Y. Fu, G. G. Siu et al., "Nitrogen binding behavior in $\mathrm{ZnO}$ films with time-resolved cathodoluminescence," Applied Surface Science, vol. 252, no. 23, pp. 8131-8134, 2006.

[34] S. Sato, R. Nakamura, and S. Abe, "Visible-light sensitization of $\mathrm{TiO}_{2}$ photocatalysts by wet-method $\mathrm{N}$ doping," Applied Catalysis A, vol. 284, no. 1-2, pp. 131-137, 2005.

[35] R. Asahi, T. Morikawa, T. Ohwaki, K. Aoki, and Y. Taga, "Visible-light photocatalysis in nitrogen-doped titanium oxides," Science, vol. 293, no. 5528, pp. 269-271, 2001.

[36] J. C. Yu, W. Ho, J. Yu, H. Yip, K. W. Po, and J. Zhao, "Efficient visible-light-induced photocatalytic disinfection on sulfurdoped nanocrystalline titania," Environmental Science and Technology, vol. 39, no. 4, pp. 1175-1179, 2005.

[37] T. Ohno, M. Akiyoshi, T. Umebayashi, K. Asai, T. Mitsui, and M. Matsumura, "Preparation of S-doped $\mathrm{TiO}_{2}$ photocatalysts and their photocatalytic activities under visible light," Applied Catalysis A, vol. 265, no. 1, pp. 115-121, 2004.

[38] T. Ohno, T. Tsubota, Y. Nakamura, and K. Sayama, "Preparation of $\mathrm{S}, \mathrm{C}$ cation-codoped $\mathrm{SrTiO}_{3}$ and its photocatalytic activity under visible light," Applied Catalysis A, vol. 288, no. 1-2, pp. 7479, 2005.

[39] A. Zaleska, P. Górska, J. W. Sobczak, and J. Hupka, “Thioacetamide and thiourea impact on visible light activity of $\mathrm{TiO}_{2}$," Applied Catalysis B, vol. 76, no. 1-2, pp. 1-8, 2007.

[40] S. Anandan, A. Vinu, K. L. P. S. Lovely et al., "Photocatalytic activity of La-doped $\mathrm{ZnO}$ for the degradation of monocrotophos in aqueous suspension," Journal of Molecular Catalysis A, vol. 266, no. 1-2, pp. 149-157, 2007.

[41] X. H. Wang, S. Liu, P. Chang, and Y. Tang, "Influence of S incorporation on the luminescence property of $\mathrm{ZnO}$ nanowires by electrochemical deposition," Physics Letters A, vol. 372, no. 16, pp. 2900-2903, 2008.

[42] B. Stypula and J. Stoch, "The characterization of passive films on chromium electrodes by XPS," Corrosion Science, vol. 36, no. 12, pp. 2159-2167, 1994.

[43] C. Shifu, Z. Sujuan, L. Wei, and Z. Wei, "Preparation and activity evaluation of $\mathrm{p}-\mathrm{n}$ junction photocatalyst $\mathrm{NiO} / \mathrm{TiO}_{2}$," Journal of Hazardous Materials, vol. 155, no. 1-2, pp. 320-326, 2008.

[44] C. Shifu, Z. Wei, Z. Sujuan, and L. Wei, "Preparation, characterization and photocatalytic activity of N-containing $\mathrm{ZnO}$ powder," Chemical Engineering Journal, vol. 148, no. 2-3, pp. 263-269, 2009.

[45] J. W. Jung, H. C. Lee, and J. S. Wang, "A study on the double insulating layer for HgCdTe MIS structure," Thin Solid Films, vol. 290-291, pp. 18-22, 1996. 

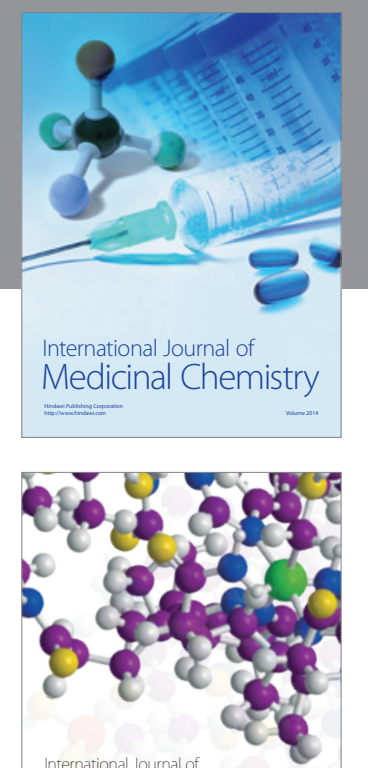

\section{Carbohydrate} Chemistry

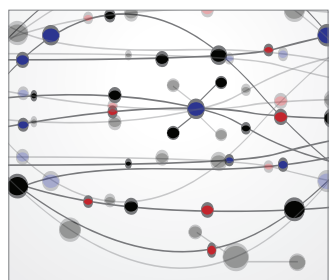

The Scientific World Journal
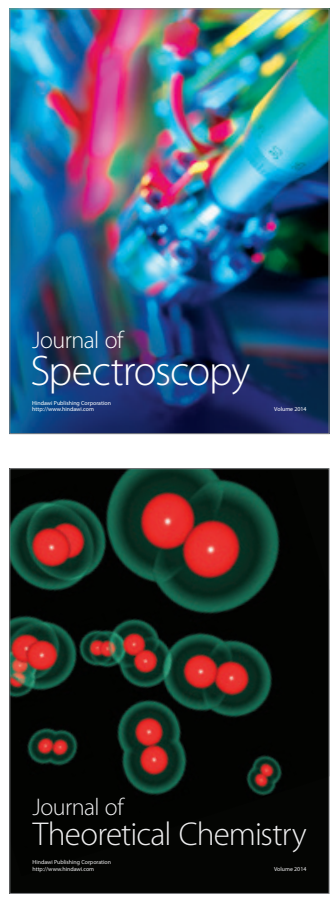
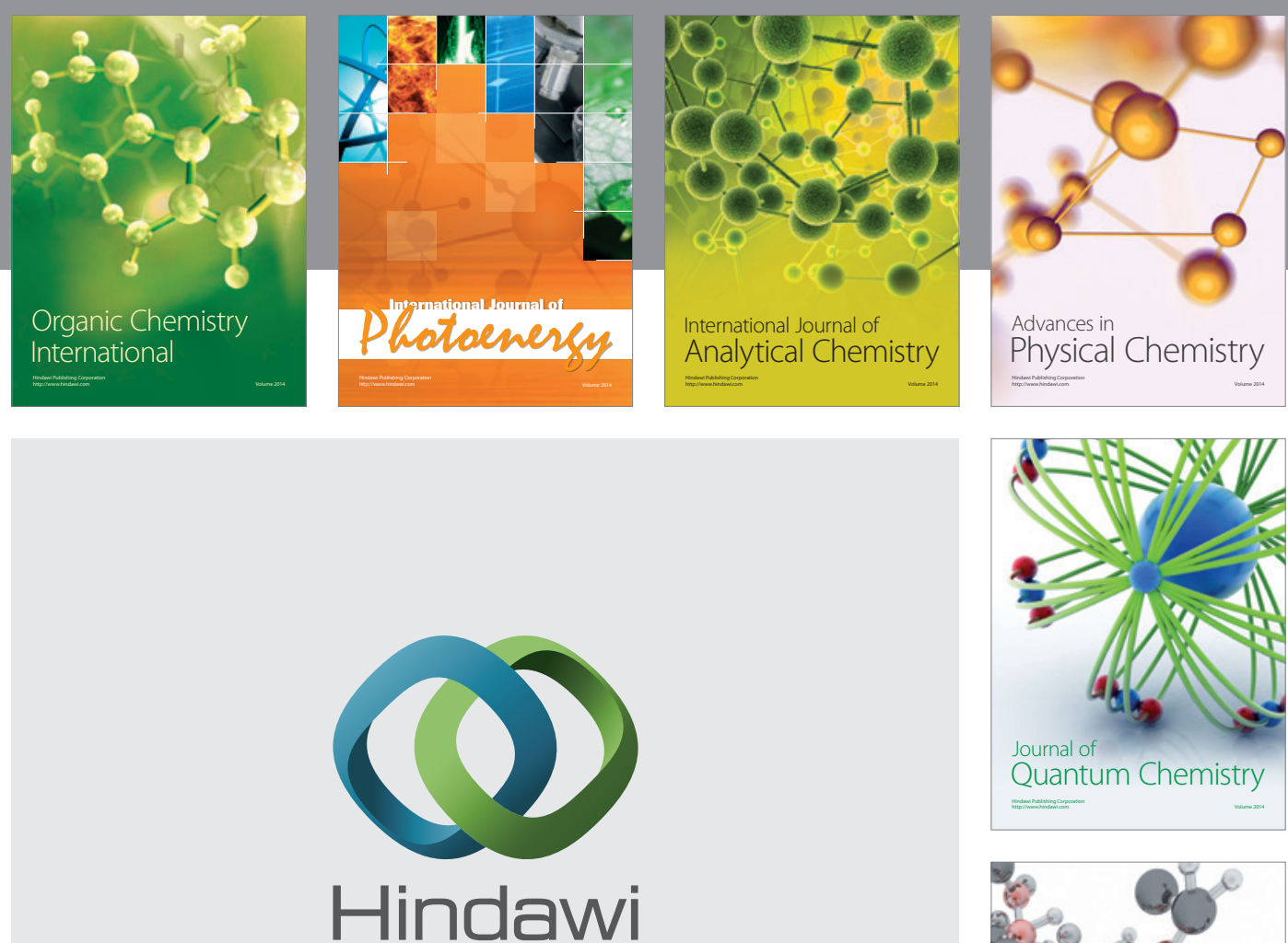

Submit your manuscripts at

http://www.hindawi.com

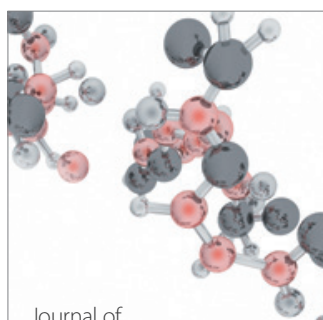

Analytical Methods

in Chemistry

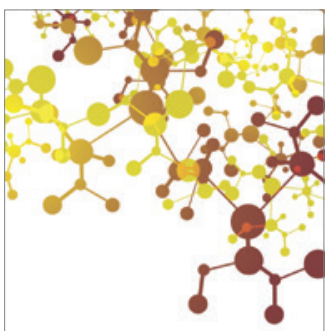

Journal of

Applied Chemistry

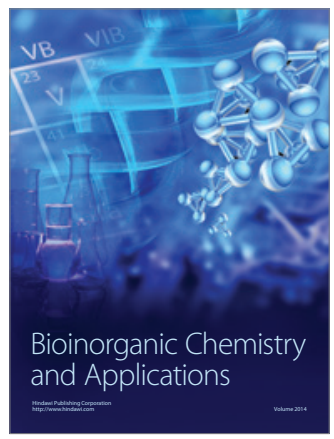

Inorganic Chemistry
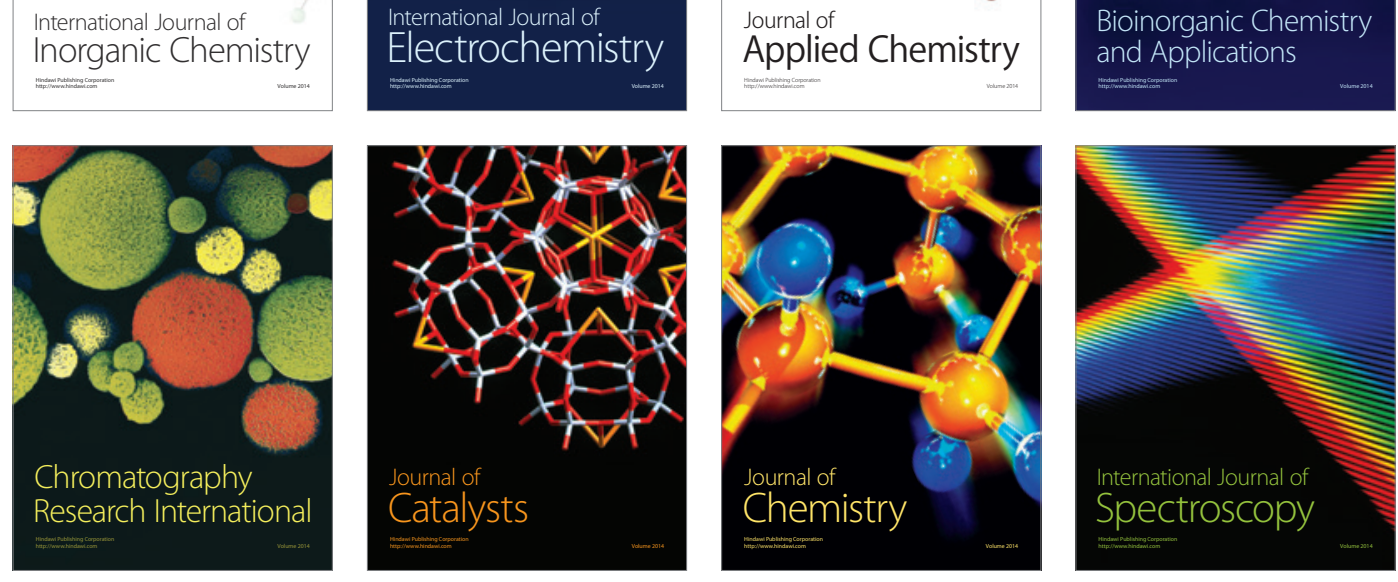